\title{
長野オリンビック施設特集 雪と氷の制御技術とその応用
}

\author{
Special Issue of Facilities for Nagano Olympic Game
} - Control Techniques of Ice and Snow and their Applications-

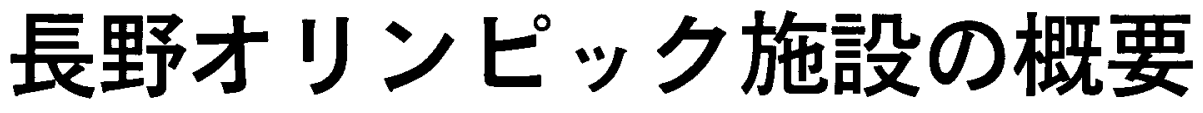

Outline of the Nagano Olympics, the game facilities, etc.

橋 本 邦 彦*
Kunihiko Hashimoto

キーワード

国際オリンピック委員会 $(\mathrm{IOC})$

国内オリンピック委員会 (NOC)

勛長野オリンピック冬季競技大会組織委員会 (NAOC)

国際スキ一連盟 (FIS)

オリンピック放送機構（ORTO）

\section{1. はじめに}

第18回オリンピック冬季競技大会は, 1998 年 2 月 に長野市，及びその周辺で開催される。

筆者は特集の編集委員として NAOC, および長 野市オリンピック局施設課に取材を行い，招致から 施設の計画，整備に至る経緯などについて，お話を うかがい資料を提供していただいた。これにもとつ き，長野オリンピックの施設の概要，環境への配虑 などについて紹介する。
2. 長野オリンピックの概要

2-1 長野オリンピックがめざすもの

大会基本理念に沿い，開催するにあたっての目標 が1994年 2 月に発表された。なかでも「自然との共 存」は招致段階からの一貫したテーマであった。

(1) 子供たちの参加促進

(2) 美しく豊かな自然との共存

(3) 平和と友好の祭典の実現

\section{2-2 開催期間と競技種目}

長野オリンピック冬季競技大会は，1998年 2 月 7 日から22日までの16日間の予定で行われる。

競技種目 7 競技 68 種目については表一 1 に示す。

\section{2-3 開催都市之競技会場地}

長野市を開倠都市とする長野オリンピックの競技 会場地は, 長野市, 山八内町 (志賀高原), 白馬村, 軽井沢町，野沢温泉村にわたっている。

*須賀工業（株）東京事業部 第一工務推進室長 


\section{表 -1 競技種目一覧表}

\begin{tabular}{|c|c|c|}
\hline 競 技 & 別 & 種 \\
\hline \multirow{6}{*}{ スキー } & アルペンスキー & $\begin{array}{l}\text { 男子: 滑降, スーパー G, 大回転, 回転, 複合 (回転・滑降) } \\
\text { 女子: 滑降, スーパー G, 大回転, 回転, 複合 }(\text { 回転・滑降) }\end{array}$ \\
\hline & $\begin{array}{l}\text { クロスカントリー } \\
\text { スキー }\end{array}$ & $\begin{array}{l}\text { 男子: } 10 \mathrm{kmC}, 15 \mathrm{kmF} / \mathrm{P}, 30 \mathrm{kmC}, 50 \mathrm{kmF}, 4 \times 10 \mathrm{~km} \text { リレー } \\
\text { 女子 : } 5 \mathrm{kmC}, 10 \mathrm{kmF} / \mathrm{P}, 15 \mathrm{kmC}, 30 \mathrm{kmF}, 4 \times 5 \mathrm{~km} \text { リレー }\end{array}$ \\
\hline & ジャンプ & $\begin{array}{l}\text { 個人 : ノーマルヒル }(\mathrm{K}=90), \text { ラージヒル }(\mathrm{K}=120) \\
\text { 団体 }(4): \text { ラージヒル }(\mathrm{K}=120)\end{array}$ \\
\hline & ノルディック複合 & $\begin{array}{l}\text { 個人 : ジャンプ }(\mathrm{K}=90), \quad \text { ロロスカントリー }(15 \mathrm{kmF}) \\
\text { 団体(4): ジャンプ }(\mathrm{K}=90), \quad \text { ロスカントリー }(4 \times 5 \mathrm{kmF})\end{array}$ \\
\hline & フリースタイルスキ- & $\begin{array}{l}\text { 男子: モーグル, エアリアル } \\
\text { 女子 : モーグル, エアリアル }\end{array}$ \\
\hline & スノーボード & $\begin{array}{l}\text { 男子 : 大回転, ハーフパイフ } \\
\text { 女子 : 大回転, ハーフパィフ }\end{array}$ \\
\hline \multirow{3}{*}{ スケート } & スピードスケート & $\begin{array}{l}\text { 男子 : } 500 \mathrm{~m}, 1,000 \mathrm{~m}, 1,500 \mathrm{~m}, 5,000 \mathrm{~m}, 10,000 \mathrm{~m} \\
\text { 女子 : } 500 \mathrm{~m}, 1,000 \mathrm{~m}, 1,500 \mathrm{~m}, 3,000 \mathrm{~m}, 5,000 \mathrm{~m}\end{array}$ \\
\hline & フィギュアスケート & 男子シングル, 女子シングル, ペア, アイスダンス \\
\hline & 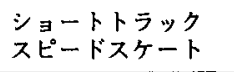 & $\begin{array}{l}\text { 男子 : } 500 \mathrm{~m}, 1,000 \mathrm{~m}, 5,000 \mathrm{~m} \text { リレー } \\
\text { 女子 : } 500 \mathrm{~m}, 1,000 \mathrm{~m}, 3,000 \mathrm{~m} \text { リレー }\end{array}$ \\
\hline \multicolumn{2}{|c|}{ アイスホッケー } & 男子, 女子 \\
\hline \multicolumn{2}{|c|}{ バイアスロン } & $\begin{array}{l}\text { 男子 : } 10 \mathrm{~km}, 20 \mathrm{~km}, 4 \times 7.5 \mathrm{~km} \text { リレー } \\
\text { 女子 : } 7.5 \mathrm{~km}, 15 \mathrm{~km}, 4 \times 7.5 \mathrm{~km} \text { リレー }\end{array}$ \\
\hline \multicolumn{2}{|c|}{ ボフススレー } & 男子: 2 人乗り，4人乗り \\
\hline \multicolumn{2}{|c|}{ リュージュ } & $\begin{array}{l}\text { 男子 : } 1 \text { 人乗り } \\
\text { 女子: } 1 \text { 人乗り } \\
2 \text { 人乗 り }\end{array}$ \\
\hline \multicolumn{2}{|c|}{ カーリンダ } & 男子, 女子 \\
\hline
\end{tabular}

\section{2-4 長野へのアクセス}

長野市は軽井沢町と高速道路で結ばれており，白 馬村, 野沢温泉村, 山八内町 (志賀高原), 飯綱高 原とはオリンピック道路がメイン交通網となる。上 信越自動車道を利用すれば，東京一長野間は 2 時間 半の所要時間である。

1997年秋には, 東京一長野間に新幹線が開通し 1 時間半で結ばれる。また, 成田（新東京国際空港） からは東京経由で約 2 時間半で到着する。長野市の 南 $56 \mathrm{~km}$ に位置する松本空港では，大阪，札幌，広島， 福岡便が運航され，空港から長野市までの所要時間 は高速道路利用で約40分である。

\section{3．長野オリンピック施設の概要}

\section{3-1 スピードスケート会場（エムウェーブ）}

長野市朝陽・大豆島地区に位置し，近くには木工 品の工場団地があり，東側には犀川と合流した千曲 川が流れている。
施設は，一周 $400 \mathrm{~m}$ の標準ダブルトラックを持つ 国内初，世界でも最大級のカバードリンクである。 外観は連続する屋根と㑡壁の連なりがアルプス連峰 を初めとする信州の山並みを表現しており，M 字 形の波がわき起こる様なその形状から「エムウェー ブ」と名付けられた。

屋根は，信州産カラマツの集成材を使用した大規 模な吊り屋根構造。大会終了後は冬期はアイスアリー ナ，他のシーズンは多目的アリーナとして使用され， オリンピック記念館の設置も計画されている。 延床面積 : 約 $76,000 \mathrm{~m}^{2}$ 地上 3 階地下 1 階 観客収容人数： 10,000 人 最高高さ：約 $43 \mathrm{~m}$ 3-2 アイスホッケーA 会場（ビックハット）

JR 長野駅の南東約 $1.5 \mathrm{~km}$ の市街地に位置している。 ゆるやかな球面を組み合わせた屋根は長野市を取り 巻く山々の連なりに呼応するようデザインされ「ビッ グハット」の愛称が付けられた。

大会後はスポーツやイベントなどの多目的ホール 
として使用される。

延床面皘 : 約 $25,240 \mathrm{~m}^{2}$ 地上 4 階地下 1 階 観客收容人数： 10,000 人 最高高さ：約 $35 \mathrm{~m}$

3-3 アイスホッケーB 会場（アクアウィング）

長野市街地の東北部にある長野運動公園内に位置 している。信州のさわやかな清流と風を表現した流 線型の大屋根をもち，空から舞い降りた翼のように 見えることから「アクアウィング」の愛称が付けら れた。開閉式の屋根がある。

大会終了後は通年の屋内プール $(50 \mathrm{~m} \cdot 25 \mathrm{~m} ・$ 飛 び込みプール）として活用される。

延床面積 : 約 $13,500 \mathrm{~m}^{2}$ 地上 3 階地下 1 階 観客収容人数： 6,000 人 最高高さ：約 $31 \mathrm{~m}$ 3-4 フィギュア/シュートトラックスピードスケー

ト会場（ホワイトリング）

長野市南東部の真島地区に位置しており，一帯は 川中島古戦場など歴史的・文化的遺産に恵まれた地 域である。

水滴が自然につくり出すゆるやかな勾配と丸みを 持つ屋根で覆われ，善光寺平にきらめく水玉をイメ一 ジしている。白く輝く形から「ホワイトリング」の 愛称が付けられた。メインアリーナとサブアリーナ から成り,フィギュアスケートの華やかさと優しさ
を表現した独創的なデザインになっている。

大会終了後は市民開放型の総合的な体育館として 活用される。

延床面積 : 約 $19,510 \mathrm{~m}^{2}$ 地上 3 階 観客収容人数： 7,351人 最高高さ: 約 $40 \mathrm{~m}$ 3-5 ボブスレー・リュージュ会場（スパイラル）

飯綱山麓の浅川地区に建設される日本で初めての 人工凍結トラックである。コースは東北向き斜面を 使用し,ボブスレーコースの長さは約 $1,360 \mathrm{~m}, 15$ のカーブがある。

「自然との共存」の結果, 世界で初めて途中 2 ケ 所の上り勾配のあるコースとなった。コース冷却に 用いられるアンモニアの量は約 $720 \mathrm{~kg}$ 。大会終了後 は，冬季は競技等に利用，また周包を含む施設全体 は家族つれで楽しめる施設として使用される。 施設面積 : 約18ha コース総延長 : 約 $1,700 \mathrm{~m}$ コース標高差 : 約 $113 \mathrm{~m}$ 延床面積 : スタートハウス，管理棟他計 9 棟 $3,980 \mathrm{~m}^{2}$ 観客収容人数 : 約 10,000 人

\section{3-6 フリースタイルスキー会場}

図ー 1 に会場平面図を示す。フリースタイルスキー は飯綱高原スキー場にある既存コースで行われる。 飯綱高原スキ一場は北信五岳の一つ飯網山の麓にあ

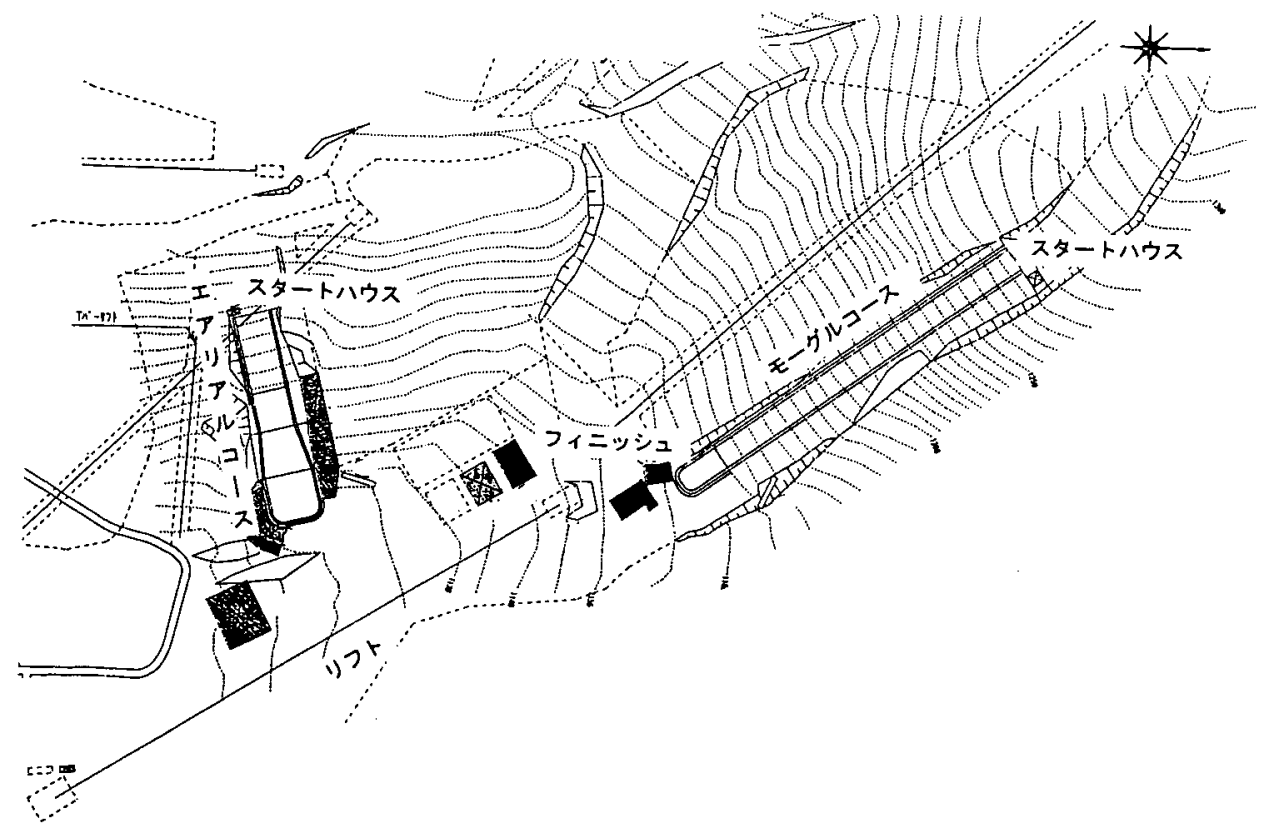

図－1 フリースタイルスキー会場平面図 
り, 善光寺平の眺望と北アルプスの絶景を眺めなが ら初級者から上級者まで幅広く楽しめるファミリー スキー場である。

1990年にはフリースタイルスキーワールドカップ 大会が開催された。モーグル，エアリアル共に公認さ

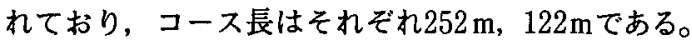

\section{3-7 アルペンスキー男女大回転会場}

図一2に会場平面図を示す。アルペンスキー男女 大回転, 回転及び複合の回転は山ノ内町の志賀高原 で，男女滑降，スーパー G 及び複合の滑降は白馬 村八方尾根で行われる。

男女大回転が行われる東館山は，標高 $2,030 \mathrm{~m}$ で， 志賀高原の中央部に位置する。東館山ダウンヒルコー スは, 標高差 $650 \mathrm{~m}$, 全長 $2,460 \mathrm{~m}$, 平均斜度 14.3 度 で，21のスキー場を有する志賀高原の中でも屈指の ロングコースである。1995年に FIS の公認を得て おり，競技はこのコースの上半分の東館山大回転コー スで行われる。楥急斜面を適度に持った変化に富ん だテクニカルなコースで, スタート地点からは長野 市街地や飯網高原, 背後には北アルプスが望める。 男子大回転 コース全長: $1,452 \mathrm{~m}$ 標高差: $450 \mathrm{~m}$ 女子大回転 コース全長: $1,259 \mathrm{~m}$ 標高差: $386 \mathrm{~m}$ 観客収容人数 : 約 20,000 人
3-8 アルペンスキー男女回転・スノーボード男女大 回転会場

図ー 3 に会場平面図を示す。会場のある焼額山は 標高 $2,009 \mathrm{~m}$ 。志賀高原のカルデラ地形の北側の外 壁を構成する内錐形の山で東側半分の斜面に，焼額 山スキー場と奥志賀高原スキー場が開設されている。

競技はこの既存のコースを使用して行われる。標 高が高く, 高冷地気候であることから乾燥した良質 の粉雪に恵まれ，自然の地形を利用した緩急の変化 に富んだコースである。

アルペンスキー 全長 : 467〜 $607 \mathrm{~m}$ 標高差 : 粎 $200 \mathrm{~m}$ スノーボード 全長 : $936 \mathrm{~m}$ 標高差 : $290 \mathrm{~m}$

観客収容人数 : 約 20,000 人

\section{3-9 スノーボード男女ハーフパイプ会場}

図ー4に会場平面図を示す。山ノ内町「かんばや しスノーボードパーク」内にある既存のコースが会 場となる。

上林は山ノ内町湯田中の東に位置する温泉街で, 志賀高原の入口にあたり，近くには猿の温泉で名高 い野猿公苑がある。大会前に FIS の基準に基つき コースの造成が行われる。

コース全長 : $110 \mathrm{~m}$ 平均斜度 $: 18$ 度 壁間の幅 : $15 \mathrm{~m}$ 壁の内部高さ : $3 \mathrm{~m}$

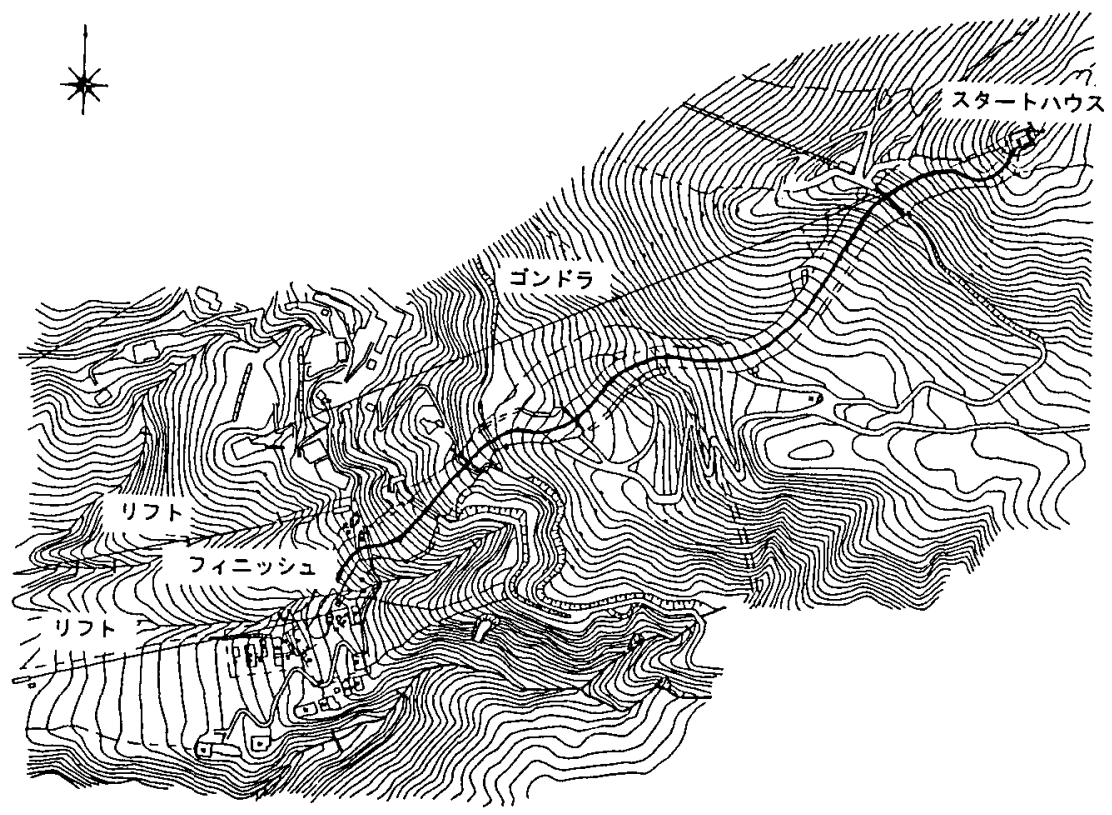

図－２アルペンスキー男女大回転会場平面図 
図一 3 アルペンスキー男女回転 ・

スノーボード男女大回転会場平面図

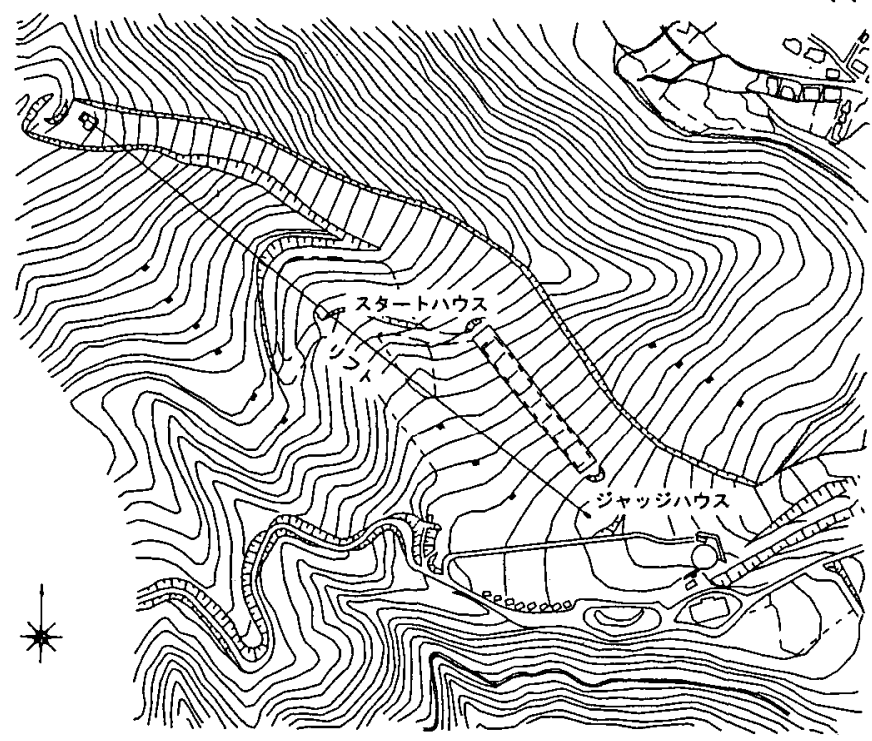

\section{図ー4 スノーボード男女ハーフハイプ 会場平面図}

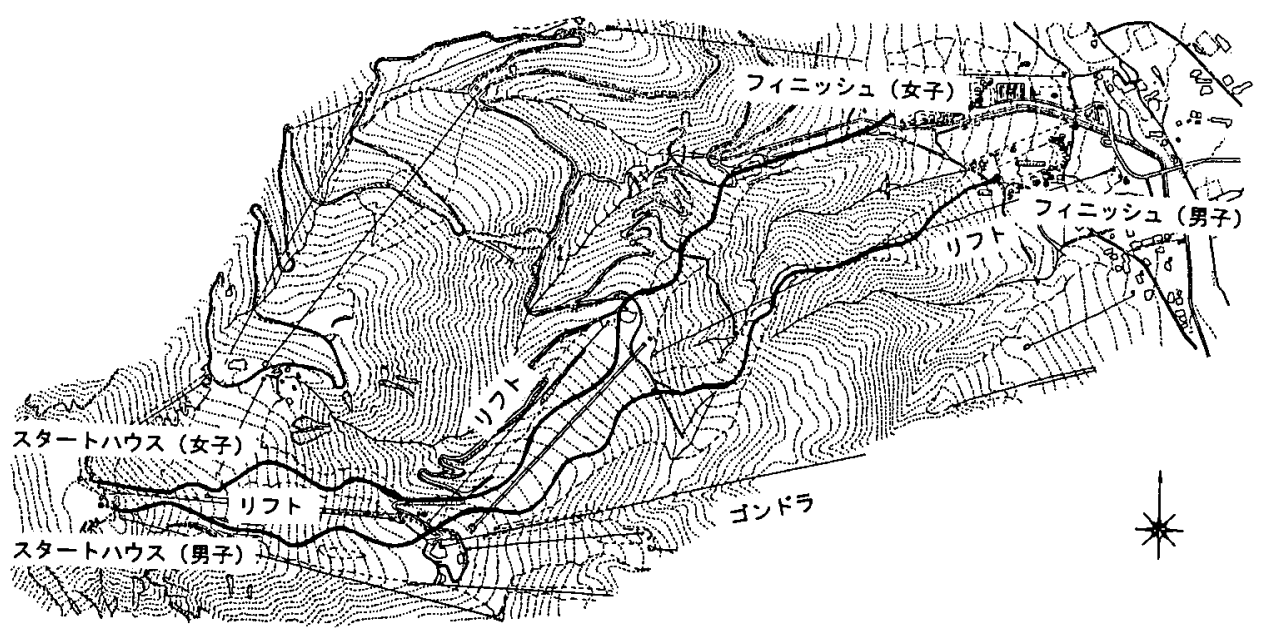

図ー5 アルペンスキー男女滑降，スーパーG 会場平面図 


\section{3-10 アルペンスキー男女滑降・スーパー G 会場}

図一 5 に会場平面図を示す。北アルプスの唐松岳 から東に張り出した尾根すそに広がる既存の八方 尾根スキー場が会場となる。このスキー場は山稜が 広く長いゲレンデを持ち，豪块なスキーが楽しめる スキ一場として年間 260 万人を越えるスキーヤーが 訪れる。

また，FIS の定める標高さ $800 \mathrm{~m}$ の滑降コースの 基準を満たしているコースは国内でも少なく，良質 の雪と相まって，毎年多くの競技大会が開催されて いる。

男子滑降 コース全長 : $2,923 \mathrm{~m}$ 標高差 : $840 \mathrm{~m}$ 女子滑降 コース全長 : 未测量 標高差 : $779 \mathrm{~m}$ 観客収容人数 : 約 20,000 人

\section{3-11 ジャンプ会場}

八方尾根スキー場の南端に設置された白馬ジャン プ競技場が会場となる。これは日本で初めて建設さ れたラージヒル，ノーマルヒル並列型のジャンプ台 である。助走路とランディングバーンがとむにやぐ ら式の世界でも珍しい構造で，スタートタワー，専 用リフト，クラブハウス，人工降雪設備などを備え た最先端の競技施設である。

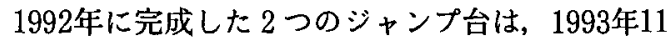
月にはオールシーズン化がされ，年間を通して競技 大会, トレーニングに利用されている。 ジャンプ台高さ：ラージヒル $138 \mathrm{~m}$ ノーマルヒル $107 \mathrm{~m}$

延床面積 : スタートタワー他計約 $1,974 \mathrm{~m}^{2}$ 敷地面積 : $12.0 \mathrm{ha}$ 観客収容人数 : 約 45,000 人

\section{3-12 クロスカントリースキー会場}

図一 6 に会場平面図を示す。白馬村神城に開設さ れるこの施設は，スタート・フィニッシュ地点とな るメイン会場を中心に，A， B， C の 3 コースが設

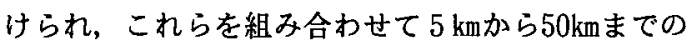
競技コースとして使用される。1997年 3 月の完成で ある。

オオタカの保護のため $5 \mathrm{~km} 4$ 本のコースが $5 \mathrm{~km} 3$ 本に変更された。競技は周回コースとなるため, 選 手がメイン会場に戻ってくる回数が多く, 観客にとっ ても，エキサイティングなレースが楽しめる。最高 標高は $860 \mathrm{~m}$ ，最大標高差は $98 \mathrm{~m}$ である。

敷地面積 : $37.7 \mathrm{ha}$ 延床面積 : 管理棟他約 $1,905 \mathrm{~m}^{2}$

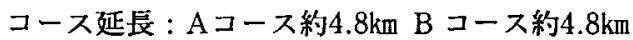
$\mathrm{C} コ ー ス$ 約 $7.8 \mathrm{~km}$ メイン会場内約 $1.5 \mathrm{~km}$

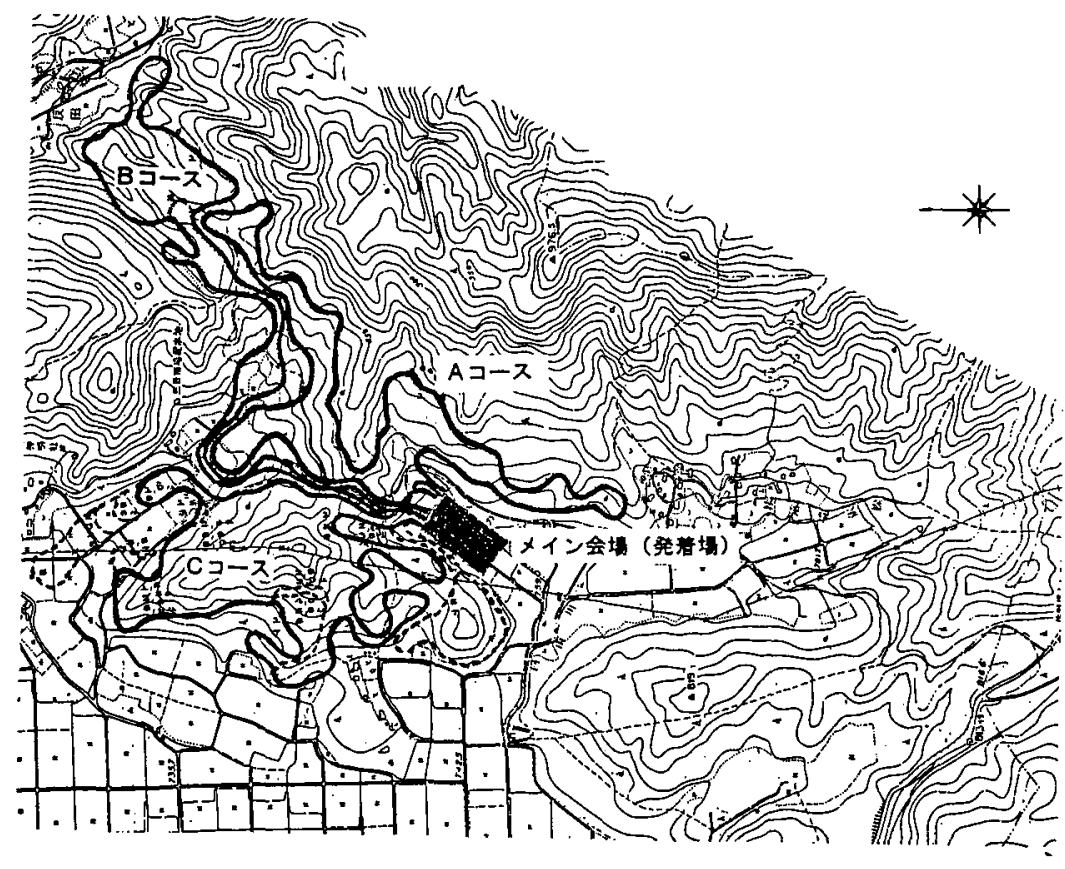

図一 6 クロスカントリースキー会場平面図 
観客収容人数 : 約 20,000 人

\section{3-13 カーリング会場}

会場となる風越公園アリーナは，国道18号線軽井 沢バイパスの南，塩沢湖近くにある既存施設で，ア リーナの他に総合運動場，屋外テニスコート，屋内 体育館，植物園などを有する総合運動公園である。

アリーナは冬期にはアイスホッケー,フィギュア スケート，カーリングなどに $60 \mathrm{~m} \times 30 \mathrm{~m}$ のアイスリ ンクとして使用され，その他のシーズンにはテニス 等年間を通じて多目的運動施設として多くの人達に 利用されている。 延床面積 : $4,271 \mathrm{~m}^{2} \quad$ 観客収容人数 : 1,700 人

\section{3-14 ハイアスロン会場}

図ー 7 に会場平面図を示す。野沢温泉スキー場の 南に隣接して開設される。オオタカの保護のため当 初の白馬村神城の予定が変更された。

会場は射場のあるメイン会場を中心に, A, B そ れぞれ $4 \mathrm{~km}$ のースが約 $1 \mathrm{~km}$ 四方の中に納められて いる。

コース延長 : A コース約 $4 \mathrm{~km} \quad \mathrm{~B}$ コース約 $4 \mathrm{~km}$ 延床面積 : 管理棟 $1,366 \mathrm{~m}^{2}$

観客収容人数 : 約 20,000 人

3-15 オリンピック村

川中島町今井地区に長野市が建設を進めている
「今井二ュータウン」が利用される。約 $19 \mathrm{ha}$ の敷地 に約1,000户の集合住宅が整備される。

宿舎・NOC オフィス, 共用施設, トレーニング 施設，オリンピック村施設からなり，1998年12月16 日から33日間にわたって開村される。

軽井沢分村は，カーリング競技に参加する選手・ 役員約 120 人の宿泊施設で，千ケ滝にある「軽井沢 スケートセンターホテル」を利用して1998年 2 月 4 日から13日間開村される。

\section{3-16 開閉会式場}

開閉会式の行われるオリンピックスタジアムは, 市街地南部の東福寺地区に長野市加整備する多目的 競技場を活用することになっている。この競技場は 主に野球場として利用されるか，大会前に仮設ス夕 ンドを整備し, 約 50,000 人分の観客席が確保される。

開催時には, 市内各所からシャトルバスが運行さ れる。1997年12月に完成する。

延床面積 : 約 $10,632 \mathrm{~m}^{2}$ 観客収容人数 : 約 50,000 人 3-17 メインプレスセンター (MPC)

長野市若里に建設される文化コンベンション施設 等を利用して開設される。ワーキングスペース棟と 会見施設棟からなり，開設期間は1998年 1 月24日か ら2月25日までである。

ワーキングスペース棟は, プレス，フォト関係者

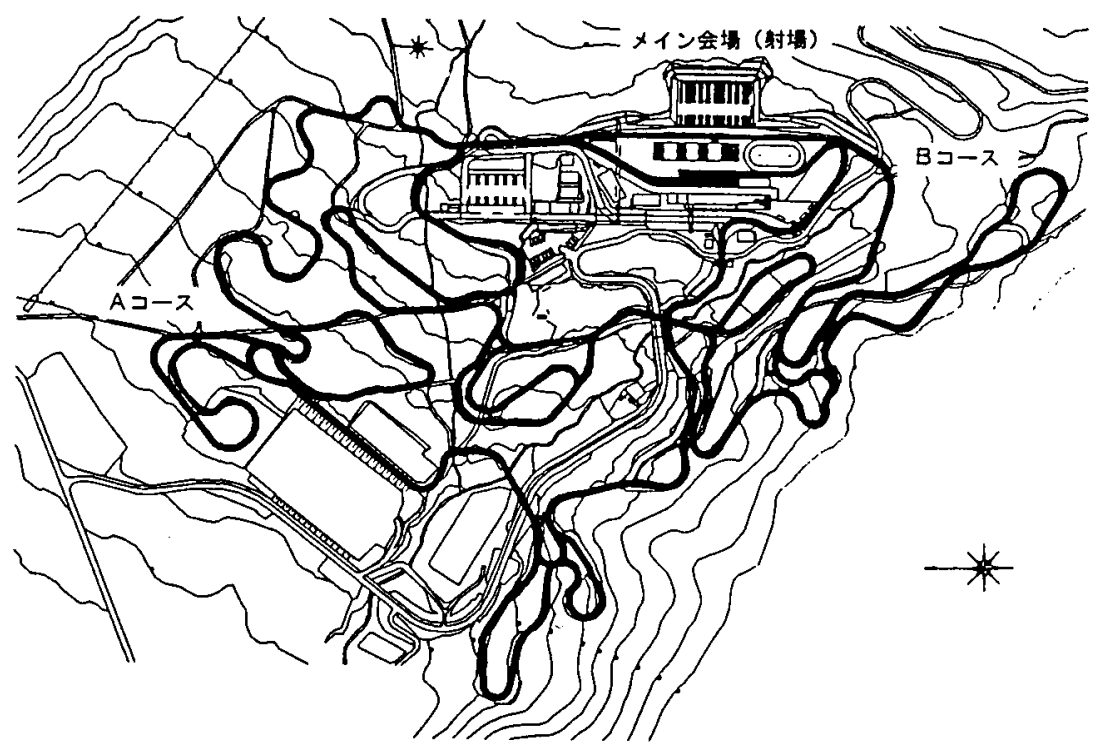

図ー 7 パイアスロン会場平面図 
が記事作成，電送等を行う拠点となり，また，イン フォメーションコーナー, フォトラボラトリー,レ ストラン, 銀行, 売店, 駐車場などあ整備される。

会見施設棟には，約 600 人が座れる記者会見場が 設けられ, 英語, フランス語, 日本語の同時通訳が 行わ机る。 延床面積: 合計 $43,067 \mathrm{~m}^{2}$

\section{3-18 サブプレスセンター（SPC）}

迅速かつ正確な取材活動を支援するため，各競技 会場, 開閉会式場, オリンピック村にサブプレスセ ンターが設置される。

MPC に準じ，ワーキングルーム，記者会見室，

飲食コーナー, インフォメーションセンターなどが

設けられる。開催期間は公式練習開始の前日から競 技終了日までである。

\section{3-19 国際放送センター (IBC)}

長野市若里にある旧紡績工場と付属建物を改修し て設置される。国際映像を制作する ORTOおよび 世界各国から集まる放映権者の本部となる。

IBC には，ORTOやNAOCの業務スペースが設 けられる他，国際信号を処理する技術設備，レスト ラン, 売店テレコムサービスなどのサービス施設も 設けられる。1997年12月に完成する。

\section{3-20メティア村}

柳町メティア村と朝陽メティア村は, 敷地面積が それぞれ約 $3.8 \mathrm{ha}$ と約 $5.7 \mathrm{ha}$ あり，長野オリンピッ クを取材する約 7,000 人のメティア関係者のための 宿泊施設とサービスセンターがある。

各メディア村には, 生活関連のレストラン, バー, 売店，銀行，コインランドリーなどがあり，開設期 間は1998年 1 月24日から 2 月25日までである。

\section{4. 長野オリンピックにおける環境への配慮}

長野オリンピックでは招致段階から一貫して「美 しく豊かな自然との共存」を目標のひとつとし，数 多くの環境問題への取り組みがなされており，ここ では主に「屋外競技会場」の整備に焦点をあてて紹 介する。

\section{4-1 自然保護検討会議}

1992年長野県が設置した自然保護検討会議は，自 然保護団体の代表，環境問題の専門家，長野県議会
議員, NAOC 競技専門委員，関係行政機関などに よって構成され，屋外競技施設整備にあたっての 「環境アセスメント調查」結果や事業者から提出さ れた環境保全対策の検討，その後のモ二タリング状 況の確認などを行って各会場毎に具体的に検討され た。

「表土復元方式」や「幼苗植栽法」といった手法 を用いた郷土種による緑化，貴重な植物や，大径木 の移植，工事によって生じた伐採木や転石などの自 然素材の有効利用，保水力を維持するための地下夕 ムの設置など多方面に検討会議の意見が反映されて いる。

また，自然環境調查の結果，オオ夕カの営巣が確 認されたため，「バイアスロン会場」がより自然環 境への影響の少ない野沢温泉村の既設コースを利用 できる会場に贸更され，「クロスカントリースキー 会場」はコースのひとつが取り止めになった。長野 市の「ボブスレー・リュージュ会場」でも，地形の 改変を低減するためにコースの縮小が行われた。

「表土復元方式」：土袞中に含まれる植物の種子や 養分等が自然の復元に役立つという事実に着目し， 建設時に開発箇所の表土を保管しておき，工事完了 後その表土を埋め戻す工法。のり面では，伐採で出 た枝を埋め込み表土の流出を防ぐ。

「幼苗植栽法」：その土地に最も適した樹木のポッ 卜苗を使い，自然の状態に近い森を短期間で作る。 管理が容易で普通なら100年以上かかって作られる 森が，短期間で作られる。

\section{4-2 既存施設の利用}

長野県内には，日本を代表するスキー場が何か所 あありこれらのスキー場を最大限に利用している。 例えばアルペンスキーの全種目とフリースタイルス キーについては既存のスキー場のコースを利用し， 野沢温泉村に変更となったバイアスロン会場につい ても，既存のクロスカントリースキーコース等を部 分的に利用することにより，新たなコースの造成を 最小限にしている。

\section{4-3 自然環境への影響の最小化}

前述のバイアスロン会場, クロスカントリースキー コースのほか, ボブスレー・リュージュコースでは 
従来に比べ長さを短縮して抑制するとともに，自然 の地形に則して土地の改変を抑制したためコースの 途中に上り坂があるという，過去に例のないユニー クなコースになっている。さらに，コースの冷却に 当たってはフロンを用いず, アンモニア間接冷却方 式を採用し，アンモニアの使用量も抑制している。

「アンモニア間接冷却方式」: コースの全面に $4 \mathrm{~cm}$ 程度の水を作るため，コンクリートのコース全体に 埋め込んだパイプに直接アンモニアを通す方式（ア ンモニア直接冷却方式）に比へ，アンモニア冷凍機 で不凍液を冷却して用いることによりアンモニアの 使用量を減らすことができる。

\section{4-4 自然の復元}

施設整備に伴いやむを得ず自然環境の改変を行う 場合は，可能な限り環境に優しい手法を用い，自然 の復元を図ることとなっている。

各競技会場では前述の「表土復元工法」「幼苗植 栽法」が採用されているほか，ジャンプ競技施設の 建設地では，白馬村天然記念物であるギフチョウの
幼虫の食草であるミヤマアオイを地元中学生のボラ ンティアにより隣接する染木林へ移植し，その後ミ ヤマアオイへのギフチョウの産卵が確認されている。 同様の取り組みはアルペン滑降のフィニッシュエリ アなどでも行われている。

\section{5.おわりに}

長野オリンピックと施設の概要, 環境への配虑な どについて紹介した。

特集取材にあたって資料の提供など，こ指導ご協 力をいただいた NAOC，および長野市オリンピッ ク局施設課の皆様に紙上をかりて厚くお礼申しあげ ます。

\section{参考資料}

1) NAOC : メティア アップティト

2) NAOC : 長野オリンピックの環境への配慮

3）長野市：ふるさとの森づくり 